\title{
The Effect of Nebivolol on Subarachnoid Hemorrhage-induced Vasospasm in the Rabbit
}

\section{Tavşanlarda Oluşturulan Subaraknoid Kanama Sonrası Gelişen Vazospazmda Nebivololün Etkisi}

\section{(D) İlker Güleç1, (D) Ali Nail İzgi2}

${ }^{1}$ University of Health Sciences, İstanbul Bağcllar Training and Research Hospital, Clinic of Neurosurgery, İstanbul, Turkey

2İstanbul University İstanbul Faculty of Medicine, Department of Neurosurgery, İstanbul, Turkey

\section{Abstract}

Objective: This study aimed to investigate the vasorelaxation effect of nebivolol on vasospasm in the rabbit model of subarachnoid hemorrhage (SAH).

Method: Single-hemorrhage model in the rabbit SAH was employed. $\mathrm{SAH}$ was induced in animals by cisterna manga injection of $4 \mathrm{~mL}$ autologous blood. Thirty-two animals were categorized into four groups: 1) control group (no SAH), 2) SAH group, 3) SAH + solvent infused group and 4) $\mathrm{SAH}+$ nebivolol treatment group. Forty-eight hours after $\mathrm{SAH}$ induction, rabbits in group 3 and in 4 were received solvent or nebivolol, respectively. Nebivolol $(0.073 \mathrm{mg} / \mathrm{kg})$ was administered via the vertebral artery in 5 minutes. Digital subtraction angiography was performed at forty-nine hour following $\mathrm{SAH}$-induced groups. The diameters of basilar arteries in four groups were measured at three points, and the average of the measurements was accepted as a consecutive result.

Results: SAH-induced rats demonstrated severe vasospasm on day 2. Angiographic vasospasm was present in group 2 (SAH only), and in 3 (SAH plus solvent). Animals in group 4 (SAH plus nebivolol) and group 1 (control), respectively, demonstrated the largest diameters of basilar arteries. Animals treated with nebivolol has reached eighty-eight percent of the value in the control group 1. There was no statistical difference between the control group and $\mathrm{SAH}$ plus nebivolol treatment group ( $p>0.05$ ). However, the difference was obtained between the groups SAH plus solvent and SAH plus nebivolol treatment $(p<0.01)$.

Conclusion: Vasospasm of the rat basilar arteries were significantly reversed by delivery of nebivolol directly into the constricted basilar artery. That drug used in cardiovascular disease may serve as a new treatment in the management of SAH patients.

Keywords: Nebivolol, subarachnoid hemorrhage, rabbit, vasospasm

\section{Öz}

Amaç: Günümüzde, subraknoid kanama (SAK) sonrası ortaya çıkan vazospazm halen etkin olarak tedavi edilememektedir. $\beta-1$ reseptör antagonisti olan nebivololün, deneysel ve klinik araştırmalarda vazodilatasyon etkisi kanıtlanmıştır. Bu çalışmada, nebivololün SAK sonrası gelişen deneysel vazospazmın tedavisindeki etkinliği araştırılmıştır.

Yöntem: Çalışmada, 32 adet Yeni Zelanda türü tavşan eşit olarak 4 gruba ayrıldı: 1) Kontrol grubu, 2) SAK grubu, 3) SAK + solvent verilen grup ve 4) $S A K+$ nebivolol tedavi grubu. İkinci, 3. ve 4. gruptaki tavşanlarda tek kanamalı SAK modeli uygulandı. Tüm deneklere dijital anjiyografi yapıldı. Üçüncü ve 4. gruptaki tavşanlarda SAK sonrası 48. saatte transfemoral yöntemle Arteria vertebralis içine yerleştirilen kateterle $1 \mathrm{~mL}$ solvent (nebivololün içinde çözünmesinde kullanılan solüsyon) veya $1 \mathrm{~mL}$ hacim içinde $0.073 \mathrm{mg} / \mathrm{kg}$ dozda nebivolol infüzyonu yapıldı. SAH uygulanan 2., 3. ve 4. grup deneklere SAK uygulamasının 49. saatinde ve 1. gruptaki deneklere dijital anjiyografi yapıldı.

Bulgular: Baziler arter ortalama çapları grup 1'de 0,64 mm, grup 2'de 0,33 mm, grup 3'te 0,37 mm ve grup 4'te 0,56 mm olarak saptandı. Íkinci gruptaki deneklerde SAK sonrası 48. saatte yapılan dijital anjiyografi incelemesinde ağır vazospazm geliştirdiği saptandı. Baziler arter çapları dikkate alındığında, istatistiksel olarak grup 1 ve 4 sonuçları arasında anlamlı fark saptanmadı $(p>0,05)$. Üçüncü grupta solvent verilen deneklerde ağır vazospazm oluşumu saptanmasına ragmen, dördüncü grupta nebivololün SAK'ye bağlı vazospazm gelişimini etkin olarak tedavi ettiği saptandı $(p<0.01)$.

Sonuç: Bu çalışmada elde edilen sonuçlar, $\beta$-1 reseptör antagonisti olan nebivololün SAK sonrası ortaya çıkan vazospazmın tedavisinde yeni bir seçenek olabilecegini ortaya koymuştur.

Anahtar kelimeler: Nebivolol, subaraknoid kanama, tavşan, vazospazm

Address for Correspondence: Illker Güleç, University of Health Sciences, İstanbul Bağcılar Training and Research Hospital, Clinic of Neurosurgery, İstanbul, Turkey

E-mail: ilkergulec@gmail.com ORCID ID: orcid.org/0000-0003-4207-238X Received: 17.04.2019 Accepted: 16.05.2019

Cite this article as: Güleç I, İzgi AN. The Effect of Nebivolol on Subarachnoid Hemorrhage-induced Vasospasm in the Rabbit. Bagcilar Med Bull 2019;4(2):42-48

${ }^{\circledR}$ Copyright 2019 by the Health Sciences University, Bagcilar Training and Research Hospital Bagcilar Medical Bulletin published by Galenos Publishing House. 


\section{Introduction}

The patients with cerebral vasospasm is a disturbance of the cerebral arteries following subarachnoid hemorrhage (SAH). A prolonged narrowing of the arteries encased in blood clots causes decreasing of blood flow in the distribution of arterial narrowing $(1,2)$. Developing delayed ischemic neurological deficit (DIND) can be permanent, or transient. Nimodipine is the only agent to reverse limitedly vasoconstriction-induced cerebral vasospasm and related DIND. Nowadays, the patients suffered DIND have a poor outcome as almost $50 \%$ ratio (1).

$\beta$-blockers called as $\beta$-adrenergic blocking agents have been using in the treatment of some cardiovascular diseases. They reduce sympathetic nervous system activity through blockade of adrenergic receptor subtypes including $\beta 1, \beta 2$, and $\beta 3$ (3). Based on historical development, there are 3 different available generations of $\beta$-blockers. The first one is nonselective $\beta$-blockers (eg, propranolol, sotalol), the second one is $\beta$-1-selective ("cardioselective") (eg, metoprolol, bisoprolol, atenolol), and the third generation shows $\beta$-1-selective activity and vasorelaxant effects (eg, carvedilol and nebivolol).

Substantial evidence showed that nebivolol could have significantly vasomotor property on the vasculature in different animal species and in humans $(4,5,6,7,8)$. Carvedilol has vasorelaxant effect mediated by $\alpha$-adrenoreceptor (AR) blockade (3). The vasodilatative effect might be organ/tissue specific, and unrelated to $\beta$ - 1 receptor and $\alpha$-AR mediated action $(9,10)$. In vitro studies demonstrated that the mechanism was associated with endothelium-dependent $(6,8)$ or endothelium-independent $(7,11)$. Molecular studies have been investigating to identify signaling pathway networks. It was obtained that endothelial nitric oxide synthase (eNOS), $\beta 3-\mathrm{AR}$, reactive oxygen species (ROS), asymmetric dimethyl arginine (ADMA), ATP stimulated P2Yreceptors and platelet-derived growth factor- $\beta$ (PDGF- $\beta$ ) could modify the cell-signaling $(8,11,12,13,14)$.

The purpose of the current study was to investigate whether the influence of nebivolol on the vasospasm following $\mathrm{SAH}$. We thought that if vasoconstriction subsequent to SAH might be ameliorated with this agent, it would be the chance of a new treatment.

\section{Material and Methods}

\section{Animals}

Thirty-two, male or female New Zealand white rabbits, weighing from 2.9-3.6 $\mathrm{kg}$ were used in this study.
Animals were housed at $22^{\circ} \mathrm{C}$ with lights on from 07:00 to 19:00 daily. All animals had free access to food and water. All surgical procedures were performed under sterile conditions at the experimental laboratory of the Department of Neurosurgery at İstanbul Faculty of Medicine.

\section{Experimental groups}

The experimental rabbit population was randomly divided into four groups: the control group $(n=8)$, the SAH group $(\mathrm{n}=8)$, the $\mathrm{SAH}+$ solvent group $(\mathrm{n}=8)$ and the $\mathrm{SAH}+$ nebivolol (in the solvent) treatment group $(\mathrm{n}=8)$. The control and SAH group has not received any treatment while the last two groups received solvent or nebivolol (in the solvent) treatment, respectively.

Treatments in the last two groups were begun at 48th following SAH induction. By a catheter placed in the A.vertebralis, the solvent or nebivolol infusion was continued for 5 minutes. After fifty-five minutes break, digital subtraction angiography (DSA) was performed in SAH only and SAH plus treated groups at the $49^{\text {th }}$ hour.

\section{Preparation of stock solutions}

The solvent is consist of a mixture of distilled water $80 \%$ and polyethylene glycol $20 \%$. The stock solution of nebivolol is prepared in a solvent as $0.2 \mathrm{mg} / \mathrm{mL}$. One $\mathrm{mL}$ of nebivolol in the solvent solution or $1 \mathrm{~mL}$ of the solvent solution were given in to via the vertebral artery and perfused at a flow rate of $0.2 \mathrm{~mL} / \mathrm{min}$.

\section{Rabbit model of SAH}

Anesthesia in the rabbit was induced with ketamine (50 mg/kg, intramuscularly) and xylazine $(10 \mathrm{mg} / \mathrm{kg}$, intramuscularly). After that, rabbits were mechanically ventilated (SW-ventilator, GF. Palmer, London, England). Inspired gas was containing $21 \% \mathrm{O}_{2}$ and $79 \%$ with room air and with a tidal volume of $12-18 \mathrm{~mL}$, respiratory rate of 12-14 breaths/minute. Oxygen saturation $\left(\mathrm{SpO}_{2}\right)$, blood pressure and exhaled $\mathrm{CO}_{2}\left(\mathrm{EtCO}_{2}\right)$ were monitored.

The auricular artery was catheterized (with $20 \mathrm{G}$ vascular catheter), for blood pressure monitoring and arterial blood sampling. In SAH group, the atlantooccipital membrane was exposed through an occipitocervical midline incision. After the withdrawal of $1 \mathrm{~mL}$ CSF, $4 \mathrm{~mL}$ of fresh autologous arterial blood was injected into the cisterna magna. Thereafter, rabbits were placed in a headdown prone position for 15 minutes. Then, the incision was sutured and returned to the cage box. 


\section{Cerebral angiography and evaluation of vasospasm}

The basilar artery was assessed by DSA in all groups. Animals were anesthetized with using the same method as described above. DSA was performed in angiography unit of Radiology Department in İstanbul Faculty of Medicine (Philips Integris V. 3000). The femoral artery was catheterized with a no. 4.0 French (Cordis, Johnson and Johnson, Florida, USA). Thereafter, continued with a no. 3.0 French of microcatheter (tracker, Boston scientific, California, USA). Under fluoroscopy control, the tip of microcatheter was placed into the left subclavian artery and $1 \mathrm{~mL}$ of contrast medium injected Iopamidol (Iopamiro $300 \mathrm{mg}$ iodine/mL, Bracco, s.p.a, Milano; ITALY). For measurements of the basilar artery's diameter, a radio positive metal was positioned under the animal's head as a reference marker of magnification. Serial angiographic imaging was collected. The diameter of the basilar artery was measured at three points including upper, medial and lower portion and recruited average value (Figure 1).

\section{Statistical Analysis}

The data in this research was measured as the differences of mean values (arterial diameter) analyzed with one-way variance analysis (One-way ANOVA) and post-hoc Tukey test. "P" value of less than 0.05 was expressed statistically significant.
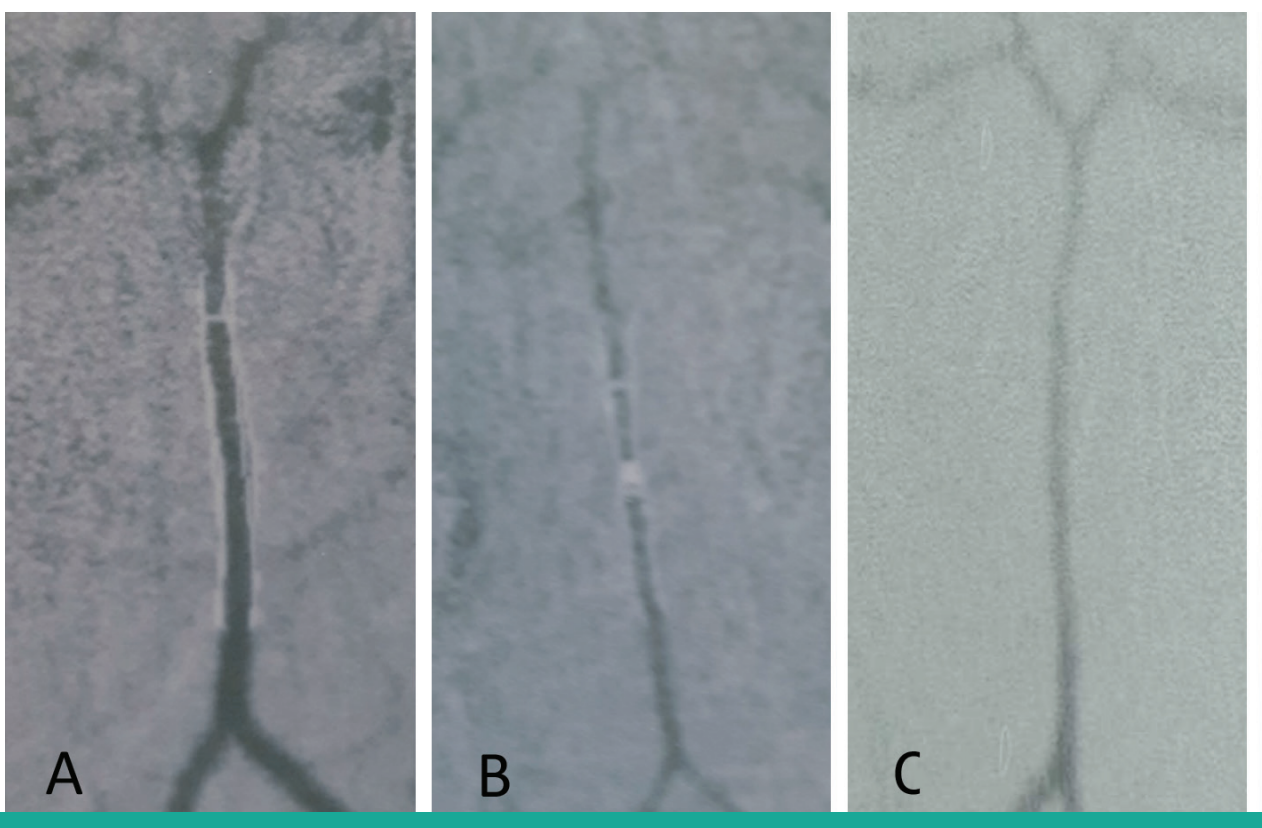

\section{Results}

Two animals (6.25\%) have died from anesthesia-induced complications in an early stage. The same number of animals were added.

The diameter of the basilar arteries was $0.64 \mathrm{~mm}$ in group 1 (no SAH), $0.33 \mathrm{~mm}$ in group 2, $0.37 \mathrm{~mm}$ in group 3 and 0.56 $\mathrm{mm}$ in group 4 (Figure 2). The average decreases in basilar arteries compared to the control group was in the last three groups as 49, 43 and 13\%, respectively. Effective vasospasm was produced in group 2 (SAH only) and 3 (SAH + solvent group). Regarding arterial narrowing, there was no statistical difference between group 2 and 3 . The solvent solution had no effect on reversing of induced vasospasm. There was no statistical difference between group control and group $\mathrm{SAH}$ plus nebivolol treatment ( $p>0.05)$. However, the difference was obtained between group SAH plus solvent and group SAH plus nebivolol treatment $(\mathrm{p}<0.001)$. So, there was no doubt that impact was belonged to nebivolol, not to the solvent solution.

Mean blood pressure (MAP) in group 4 was decreased $\sim 15 \%$, started forty-five minutes after infusion of nebivolol, normalized at the third hour. Heart rate (HR) in group 4 was decreased $12 \%$, started fifteen minutes after infusion of nebivolol, normalized at the sixth hour. No significant changes in MAP and HR were observed in other groups. We have preferred short time infusion of nebivolol. In our

Figure 1. Digital subtraction angiography: A) Control, B) SAH, C) SAH plus the solvent, D) SAH plus nebivolol. Right the vertebral artery injection revealed severe vasospasm in the group SAH and SAH plus the solvent, and mild vasospasm in group SAH plus nebivolol

SAH: Subarachnoid hemorrhage 


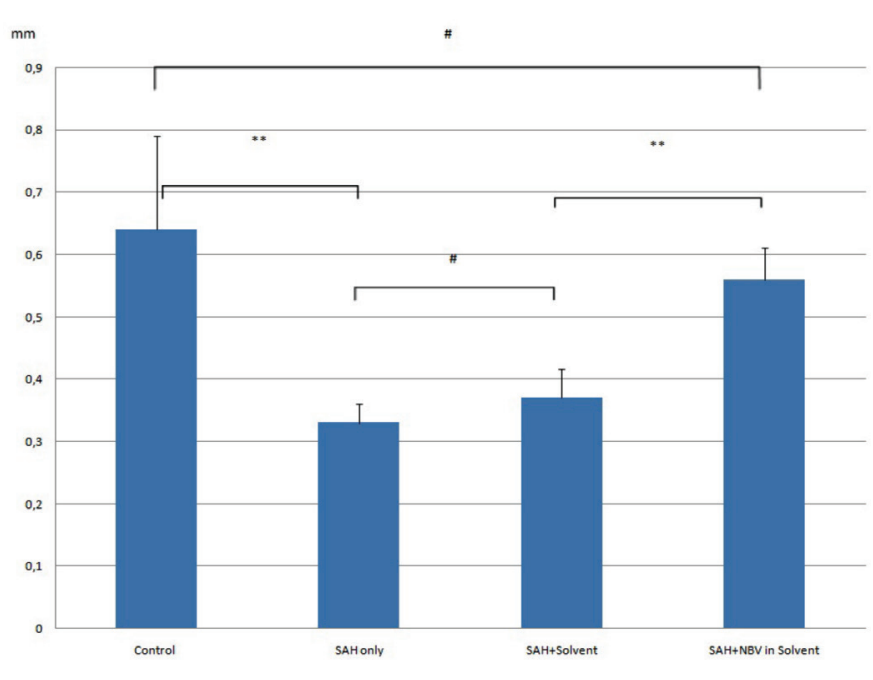

Figure 2. The diameters of the basilar arteries measured by angiography. The diameter of the basilar arteries was 0.64 $\mathrm{mm}$ in group 1 (no SAH), $0.33 \mathrm{~mm}$ in group $2,0.37 \mathrm{~mm}$ in group 3 and $0.56 \mathrm{~mm}$ in group 4 . There was no statistical difference between group control and group SAH plus nebivolol treatment ( $\mathrm{p}>0.05)$. Group of SAH plus nebivolol treatment's result is significantly different from group 2 and 3 [(\#non-significant $(\mathrm{p}>0.05),{ }^{* *}$ very significant $(\mathrm{p}<0.001)]$

experiment which prevented to occur a big issue. If infusion time is prolonged in the future, that problem needs to be resolved.

\section{Discussion}

Rats, cats, rabbits, dogs, and primates are used as the model for SAH-induced vasospasm (2). SAH is induced with different volumes of blood by using different surgical methods. The majority of animal models of SAH can create an effective degree of vasospasm. However, they did mostly not mimic pathological and pathophysiological changes seen in human (2). So, all models can provide a limited amount of data extrapolated to human. Although suitable animal for this purpose is dog and primate. Using those animal models are getting harder because of ethic and costing problems. In this experiment, we have chosen the rabbit model of SAH. This model exerts biphasic pattern of vasospasm (15) and morphological changes in constricted arteries (16) similar to observed in humans. Another advantage is to be easier for performing DSA. In our current study, we have created angiographic vasospasm in the rabbit model of SAH to test the nebivolol's effect.

From the literature review, nebivolol has an impact as the widening of constricted vasculature $(4,6,9)$. Mechanisms of the action of nebivolol-induced vasodilation have occurred in several pathways including the endothelial-dependent and -independent manner. The main mechanism due to the action of nebivolol is accepted by evoking NOinduced vasorelaxation. In vitro studies, nebivolol -induced vasodilation effect was abolished by NOS inhibitor or by removal of or damage to the endothelium (6). Its effect was could not be reversed by the $\alpha$-receptor inhibitor, the cyclooxygenase inhibitor or by serotonin inhibitor. Another study showed that there was a sustained increase in eNOS expression resulted in induced NO-dependent relaxation (8). Similar results were obtained as in vivo studies that NOS inhibitors blocked NO-mediated venous relaxation of the forearm (4), and of forearm arterial system (5) in humans.

ATP stimulated P2Y-receptor and $\beta 3$-AR activation may be one of the underlying vasodilation by NO-induced. Exposure of cultured human endothelial cells to nebivolol and addition of external ATP to the medium results in NO release (14). Moreover, ATP produces fast-acting NO release than nebivolol's. ATP-activated P2Y receptor leads to activation of guanyl cyclase by the eNOS (14). If the P2Y receptor activity were tightly blocked by the selective antagonist, the availability of $\mathrm{NO}$ was significantly decreased. Therefore, it is criticized that ATP output from endothelial cells has a major role in increasing of nebivololinduced NO (17).

Asymmetric dimethyl arginine (ADMA) is the endogenous inhibitor of NOS. Elevation of ADMA is associated with low levels of NO leading to endothelial dysfunction (18). Accumulation of ADMA cause to decrease NO amount, consequently. It might contribute to the vasospasm following SAH. Nebivolol induces the dimethyl arginine dimethyl amino hydrolase 2 (DDAH2) activity that increases protein breakdown and thereby reduce the production of ADMA (19). That pathway may be partially complementary to the occurrence of the vasoactive impact. In this regard, additional studies are needed.

Newly identified mechanism of vasorelaxant effect by nebivolol is the $\beta 3-\mathrm{AR}$ pathway. It was revealed that $\beta 3$ AR agonists have produced vasodilation in different animal species $(9,10)$. Many studies were performed to characterize the vasorelaxant effect of $\beta 3$-AR elicited endothelial-dependent or -independent manner. In an endothelial-dependent manner, the endothelium is critically required for its vascular response. $\beta 3$-AR-induced relaxation was substantially decreased after endothelium denied which suggests that those receptors were mainly in vascular endothelium (11). Administration of the $\beta 3$ $\mathrm{AR}$ antagonist disrupted the enzymatic function of eNOS 
activity and inhibited NO release. The endotheliumdependent effect occurs via the NOS/NO/cGMP signaling pathway, respectively. The other pathway is the endothelium-independent signaling road. In rat thoracic aorta, the source of NO generated from the endotheliumindependent mechanism could not be directly related to NOS (9). Because NOS inhibitors have failed an increase of $\mathrm{NO}$ production while achieved with selective $\beta 3$-AR inhibitors. AR-induced relaxation of rat abdominal aorta has mostly used cyclic adenosine monophosphate (cAMP) in an independent pathway (7). Recent studies have shown that $\mathrm{K}+$ channel-mediated vasodilatation including BKCa, KATP, and KV is activated by the $\beta 3-\mathrm{AR}(7,11)$. In human endothelium, the NO synthase - independent relaxation was completely inhibited by $\mathrm{K}+$ channel inhibitors (11). In another study, dose-dependent relaxation effect was encountered in the canine arterial rings with intracellular high-level cAMP levels in $\mathrm{K}+$ channel studies. Regarding the study of mechanism, the adenylate cyclase/cAMP pathway is used in endothelium-independent mechanism related $\beta 3$-AR. It should be another pathway of NO production by $\beta 3$-ARs.

Another determinant factor in the pathophysiology of vasospasm is ROS. Intracellular ROS formation causes leading to oxidative stress, cell damage, and apoptosis (20). Increased ROS levels in the brain have been shown to be increased following SAH (21). A large amount of ROS acts scavenging of NO resulted in decreased NO availability. It may cause vascular dysfunction, which is parallel to the development of cerebral vasospasm (22). In cell cultured study, it has been shown that nebivolol is highly sensitive to act as ROS scavenger (12). In addition, nebivolol and its hepatic metabolites effectively alleviated oxidative stress, markedly decreased the ROS concentration (23). In oxidative stress condition after SAH, ROS defense mechanisms including superoxide dismutase and glutathione peroxidase were activated. The existence of an increased level of both enzymes in patients with cerebral vasospasm was found (24). Nebivolol may exert anti-vasospastic effects on cerebral vasospasm obtained current study through changing of related enzyme's activity. In some cardiovascular disease, nebivolol could also substantially upregulate some ROS related genes (25). Further studies are needed.

Cerebral vasospasm involves multiple processes including inflammation, vascular proliferation, and matrix alteration (13). Promoting to vascular remodeling, cell growth and proliferation of vascular smooth muscle cells (VSMC) result in a restricted or a permanent stopping of blood flow. Recently, it has been reported that PDGF- $\beta$, proliferating cell nuclear antigen and $\alpha$-smooth muscle actin in VSMCs was increased after SAH (13). PDGF has the ability to create vasoconstriction in cerebral arteries (26). Apoptosis and proliferation induced in coronary artery VSM and endothelial cells were significantly inhibited concentration-dependently by nebivolol in human (27). The effect of nebivolol may be due to the impairing of PDGF signaling $(27,28)$. In addition, nebivolol substantially prevented neo-intimal thickening identified after balloon-injured carotid arteries in the rat model (29). In a study, nebivolol inhibits pro-inflammatory genes expression as VCAM-1, E-selectin, MCP-1 by modulating NF-B dependent genes (29). In human VSMC exposed to nebivolol, changes of proinflammatory cytokines and the increase of $\mathrm{NO}$ was obtained (28). Therefore, it was thought that the regulation of eNOS expression by nebivolol inhibited NF-kappa B. Furthermore, the elevated neutrophillymphocyte ratio (NLR) is accepted as an inflammation biomarker for some vascular disease such as coronary heart disease, hypertension. Nebivolol has a strong impact on reducing NLR (30).

Platelets are activated by contact with exposed collagen and aggregate together at the injured sites leading to the formation of a thrombus. The NOS is present in platelets which is a key role for aggregation inhibition. It was shown that nebivolol exerted to prevent platelet aggregation via activating NOS which caused NO increase (31). It could be hypothesized that thrombus deposition could cause lowlevel production of NO that might increase the degree of vasospasm.

\section{Conclusion}

The advances in molecular biology make easier to understand the pathophysiology of SAH-induced vasospasm in human. Improving experimental SAH models provides significant contributions to the multifactorial nature of the disease. However, all experimental studies have some limitations. Unfortunately, there is still no acceptable treatment method.

The results of the current study provide important data that nebivolol treated angiographic vasospasm following $\mathrm{SAH}$ in rabbits. In summary, nebivolol might alleviate $\mathrm{SAH}-$ induced cerebral vasospasm in human and may contribute improvement of patient outcomes in the future. 


\section{Ethics}

Ethics Committee Approval: This study was done as a thesis almost 20 years ago. There were not ethical committees of today in those times. The subjects used in the study was obtained from İstanbul University DETAM after the thesis had been given from the lecturer; it had been approved by the department academical committee.

Informed Consent: Experimental study.

Peer-review: Externally peer-reviewed.

\section{References}

1. Hop JW, Rinkel GJ, Algra A, van GJ. Case-fatality rates and functional outcome after subarachnoid hemorrhage: a systematic review. Stroke 1997;28:660-664.

2. Marbacher S, Gruter B, Schopf S, Croci D, Nevzati E, D'Alonzo D, et al. Systematic review of in vivo animal models of subarachnoid hemorrhage: species, standard parameters, and outcomes. Transl Stroke Res 2018;12. doi: 10.1007/s12975-018-0657-4.

3. do Vale GT, Ceron CS, Gonzaga NA, Simplicio JA, Padovan JC. Three Generations of beta-blockers: History, Class Differences and Clinical Applicability. Curr Hypertens Rev 2019;15:22-31.

4. Bowman AJ, Chen CP, Ford GA. Nitric oxide mediated venodilator effects of nebivolol. Br.J.Clin.Pharmacol. 1994;38:199-204.

5. Cockcroft JR, Chowienczyk PJ, Brett SE, Chen CP, Dupont AG, Van NL, et al. Nebivolol vasodilates human forearm vasculature: evidence for an L-arginine/NO-dependent mechanism. J Pharmacol Exp Ther 1995;274:1067-1071.

6. Gao YS, Nagao T, Bond RA, Janssens WJ, Vanhoutte PM. Nebivolol induces endothelium-dependent relaxations of canine coronary arteries. J Cardiovasc Pharmacol 1991 Jun;17:964-969.

7. Matsushita M, Tanaka Y, Koike K. Studies on the mechanisms underlying beta-adrenoceptor-mediated relaxation of rat abdominal aorta. J Smooth Muscle Res 2006;42:217-225.

8. Parenti A, Filippi S, Amerini S, Granger HJ, Fazzini A, Ledda F. Inositol phosphate metabolism and nitric-oxide synthase activity in endothelial cells are involved in the vasorelaxant activity of nebivolol. J Pharmacol Exp Ther 2000;292:698-703.

9. Ignarro LJ, Byrns RE, Trinh K, Sisodia M, Buga GM. Nebivolol: a selective beta(1)-adrenergic receptor antagonist that relaxes vascular smooth muscle by nitric oxide- and cyclic GMPdependent mechanisms. Nitric Oxide 2002;7:75-82.

10. Shen YT, Cervoni P, Claus T, Vatner SF. Differences in beta 3-adrenergic receptor cardiovascular regulation in conscious primates, rats and dogs. J.Pharmacol Exp Ther 1996;278:14351443.

11. Dessy C, Moniotte S, Ghisdal P, Havaux X, Noirhomme P, Balligand JL. Endothelial beta3-adrenoceptors mediate vasorelaxation of human coronary microarteries through nitric oxide and endothelium-dependent hyperpolarization. Circulation 2004;110:948-954.

12. de Groot AA, Mathy MJ, van Zwieten PA, Peters SL. Antioxidant activity of nebivolol in the rat aorta. J Cardiovasc Pharmacol 2004;43:148-153.
13. Duan H, Zhang J, Li L, Bao S. Effect of simvastatin on proliferation of vascular smooth muscle cells during delayed cerebral vasospasm after subarachnoid hemorrhage. Turk Neurosurg 2016;26:538-544.

14. Mason RP, Jacob RF, Corbalan JJ, Szczesny D, Matysiak K, Malinski T. The favorable kinetics and balance of nebivolol-stimulated nitric oxide and peroxynitrite release in human endothelial cells. BMC Pharmacol Toxicol 2013;14:48.

15. Chan RC, Durity FA, Thompson GB, Nugent RA, Kendall M. The role of the prostacyclin-thromboxane system in cerebral vasospasm following induced subarachnoid hemorrhage in the rabbit. J Neurosurg 1984;61:1120-1128.

16. Liszczak TM, Black PM, Tzouras A, Foley L, Zervas NT. Morphological changes of the basilar artery, ventricles, and choroid plexus after experimental SAH. J Neurosurg 1984;61:486-493.

17. Jankowski M, Szczepanska-Konkel M, Kalinowski L, Angielski S. Cyclic GMP-dependent relaxation of isolated rat renal glomeruli induced by extracellular ATP. J Physiol 2001;530(Pt 1):123-130.

18. Garbin U, Pasini AF, Stranieri C, Manfro S, Boccioletti V, Cominacini L. Nebivolol reduces asymmetric dimethylarginine in endothelial cells by increasing dimethylarginine dimethylaminohydrolase 2 (DDAH2) expression and activity. Pharmacol Res 2007;56:515-521.

19. Hermenegildo C, Medina P, Peiro M, Segarra G, Vila JM, Ortega J, Lluch S. Plasma concentration of asymmetric dimethylarginine, an endogenous inhibitor of nitric oxide synthase, is elevated in hyperthyroid patients. J Clin Endocrinol Metab 2002;87:5636-5640.

20. Redza-Dutordoir M, Averill-Bates DA. Activation of apoptosis signalling pathways by reactive oxygen species. Biochim Biophys Acta 2016;1863:2977-2992.

21. Erdi F, Keskin F, Esen H, Kaya B, Feyzioglu B, Kilinc I, et al. Telmisartan ameliorates oxidative stress and subarachnoid haemorrhageinduced cerebral vasospasm. Neurol Res 2016;38:224-231.

22. Mori T, Nagata K, Town T, Tan J, Matsui T, Asano T. Intracisternal increase of superoxide anion production in a canine subarachnoid hemorrhage model. Stroke 2001;32:636-642.

23. Evangelista S, Garbin U, Pasini AF, Stranieri C, Boccioletti V, Cominacini L. Effect of DL-nebivolol, its enantiomers and metabolites on the intracellular production of superoxide and nitric oxide in human endothelial cells. Pharmacol Res 2007;55:303-309.

24. Gaetani P, Pasqualin A, Baena R, Borasio E, Marzatico F. Oxidative stress in the human brain after subarachnoid hemorrhage. J Neurosurg 1998;89:748-754.

25. Garbin U, Fratta PA, Stranieri C, Manfro S, Mozzini C, Boccioletti $\mathrm{V}$, et al. Effects of nebivolol on endothelial gene expression during oxidative stress in human umbilical vein endothelial cells. Mediators Inflamm 2008;2008:367590.

26. Zhang ZW, Yanamoto H, Nagata I, Miyamoto S, Nakajo Y, Xue JH, Iihara K, Kikuchi H. Platelet-derived growth factor-induced severe and chronic vasoconstriction of cerebral arteries: proposed growth factor explanation of cerebral vasospasm. Neurosurgery 2010;66:728-735.

27. Brehm BR, Wolf SC, Bertsch D, Klaussner M, Wesselborg S, Schuler $\mathrm{S}$, et al. Effects of nebivolol on proliferation and apoptosis of human coronary artery smooth muscle and endothelial cells. Cardiovasc Res 2001;49:430-439.

28. Wolf SC, Sauter G, Jobst J, Kempf VA, Risler T, Brehm BR. Major differences in gene expression in human coronary smooth muscle cells after nebivolol or metoprolol treatment. Int J Cardiol 2008;125:4-10. 
29. Wolf SC, Sauter G, Preyer M, Poerner T, Kempf VA, Risler T, et al. Influence of nebivolol and metoprolol on inflammatory mediators in human coronary endothelial or smooth muscle cells. Effects on neointima formation after balloon denudation in carotid arteries of rats treated with nebivolol. Cell Physiol Biochem 2007;19:129-136.

30. Hussain M, Saeed M, Babar MZM, Atif MA, Akhtar L. Nebivolol attenuates neutrophil lymphocyte ratio: a marker of subclinical inflammation in hypertensive patients. Int $\mathrm{J}$ Hypertens 2017;2017:7643628.

31. Falciani M, Rinaldi B, D’Agostino B, Mazzeo F, Rossi S, Nobili B, et al. Effects of nebivolol on human platelet aggregation. J Cardiovasc Pharmacol 2001;38:922-929. 